Review

\title{
Standardised Parenteral Nutrition
}

\author{
Karen Simmer ${ }^{1,2, *}$, Abhijeet Rakshasbhuvankar ${ }^{1}$ and Girish Deshpande ${ }^{3,4}$
}

1 Department of Neonatal Paediatrics, King Edward Memorial Hospital for Women and Princess

Margaret Hospital for Children, Subiaco, WA 6008, Australia;

E-Mail: abhijeet.rakshasbhuvankar@health.wa.gov.au

2 Centre of Neonatal Research and Education, School of Paediatrics and Child Health, University of Western Australia, Crawley, WA 6009, Australia

3 Department of Neonatal Paediatrics, Nepean Hospital, Kingswood, NSW 2747, Australia;

E-Mail: Girish.Deshpande@swahs.health.nsw.gov.au

4 Sydney Medical School Nepean, University of Sydney, Sydney, NSW 2747, Australia

* Author to whom correspondence should be addressed; E-Mail: karen.simmer@health.wa.gov.au; Tel.: +61-893-401-260; Fax: +61-893-401-266.

Received: 4 February 2013; in revised form: 18 March 2013 / Accepted: 19 March 2013 / Published: 28 March 2013

\begin{abstract}
Parenteral nutrition (PN) has become an integral part of clinical management of very low birth weight premature neonates. Traditionally different components of PN are prescribed individually considering requirements of an individual neonate (IPN). More recently, standardised PN formulations (SPN) for preterm neonates have been assessed and may have advantages including better provision of nutrients, less prescription and administration errors, decreased risk of infection, and cost savings. The recent introduction of triple-chamber bag that provides total nutrient admixture for neonates may have additional advantage of decreased risk of contamination and ease of administration.
\end{abstract}

Keywords: premature; nutrition; standardised parenteral nutrition; individualised parenteral nutrition; total nutrient admixtures; triple-chamber bag

\section{Introduction}

The placenta is the only source of nutrition for growing fetus during the intrauterine life. Neonates delivered at less than 30 weeks gestation are born at a time of rapid brain and body growth. Abrupt 
cessation of the placental supply of nutrients at birth makes these premature neonates vulnerable to nutritional deficiencies unless enteral or parenteral nutrition is established rapidly. In very premature neonates enteral feeding is often established slowly and therefore, during this period, nutrients are provided parenterally in the form of parenteral nutrition (PN). Traditionally, different components of PN for neonates are prescribed individually taking into consideration the biochemical, nutritional and physiological status of the neonate. However, standardised PN (SPN) combinations have been evaluated and may have some advantages over the individualised PN (IPN) regimen.

Very low birth weight (VLBW) neonates have changing physiology and clinical condition during the first few days of life. It is reasonable to think that PN ordered considering unique requirements of a particular newborn infant will be the most appropriate and will give the best possible outcome in terms of biochemical control, nutrient intake and weight gain. However, studies have indicated that most premature neonates tolerate mild to moderate variations in nutritional intake and majority of those can be managed with few sets of standard PN solutions [1,2].

\section{SPN Formulations}

SPN formulations are in use in many Neonatal Intensive Care Units (NICUs) across Australia. These PN formulations are available commercially or can be made in-house by hospital pharmacist.

There were over 60 different neonatal PN formulations supplied by Baxter ${ }^{\circledR}$ across Australia and New Zealand. These PN formulations have a shelf life up to 40 days at $2-8{ }^{\circ} \mathrm{C}$. Collaboration between NICUs has recently greatly reduced the number and cost of commercial formulations (Bolisetty, PSANZ Sydney abstract).

In our NICU (King Edward Memorial Hospital for Women, Western Australia), SPN has been made by our pharmacist for over a decade. We have formulations with glucose concentrations of $6 \%$, $8 \%, 10 \%$ and $12 \%$ and amino acid concentrations of 1,2 and $3 \mathrm{~g} / 100 \mathrm{~mL}$ with standard amount of electrolytes and vitamins. These formulations are made in our hospital pharmacy during the working-hours seven days a week. After-hours for a new patient, we use commercially available SPN (Starter TPN) $\left(\right.$ Baxter $\left.^{\circledR}\right)$ containing amino acid $(1.5 \mathrm{~g} / 100 \mathrm{~mL})$ and glucose $(5 \%$ or $7.5 \%)$ until pharmacy-made PN is available. We start $20 \%$ olive oil based lipid emulsion $\left(\right.$ ClinOleic $^{\circledR}$, Baxter $^{\circledR}$ ) at a dose of $1 \mathrm{~g} / \mathrm{kg}$ within $24 \mathrm{~h}$ of birth. Olive oil based lipid emulsions have been found to be well tolerated by critically ill and preterm neonates. [3-6]. Several in vitro and animal studies have reported suppression of T-lymphocyte function and impaired bacterial clearance by soybean oil based lipid emulsion compared with minimal effect from olive oil based emulsion. [7]. In addition there are concerns regarding excess of poly-unsaturated fatty acids (PUFAs) and low vitamin E levels in soybean oil based lipid emulsions [8]. Although, the clinical studies have failed to show any short term benefits of using olive oil based emulsions on fatty acid profile and anti-oxidant properties, the fatty acid profile of preterm neonates in Clinoleic group was similar to breast milk fed preterm neonates [4-6]. ClinOleic ${ }^{\circledR} 20 \%$ lipid emulsion contains a mixture of $80 \%$ olive oil and $20 \%$ soybean oil and is given as a $24 \mathrm{~h}$ infusion piggy-backed to the rest of the PN solution containing glucose, amino acids, electrolytes and vitamins. When given $160 \mathrm{~mL} / \mathrm{kg} /$ day volume, the SPN containing $2 \mathrm{~g} / 100 \mathrm{~mL}$ amino acids, $12 \%$ glucose and $3 \mathrm{~g} / \mathrm{kg}$ of lipid emulsion gives $114 \mathrm{Kcal} / \mathrm{kg}$ of energy and $3.2 \mathrm{~g} / \mathrm{kg}$ of proteins. 
This nutrient intake is consistent with recent ESPGHAN guidelines which recommend energy intake of $110-120 \mathrm{Kcal} / \mathrm{kg}$ and protein intake of 3-4 g/ $\mathrm{kg}$ body weight in premature infants [9].

\section{3. $P N$ in Premature Neonates}

One of the most significant therapeutic advances of 20th century came when Dudrick et al. demonstrated practical method of providing total nutrition intravenously [10]. Initial need for intravenous nutrition was perceived in the post-operative adult patients who were kept fasting for extended period of time. It was seen that under-nutrition in these patients was associated with increased morbidity and mortality. Over the last 60 years, the indications, objectives, constituents and methods of administration of PN have evolved.

Nutrition of the newborn infant, previously often a neglected issue, has been gaining increasing importance in acute clinical management. It is becoming clear that early nutrition in the critical period plays an important role in the long-term health and neuro-development. Experimental studies in animals have shown that nutrition in the critical period of life can affect brain structure and function irreversibly [11,12]. Postnatal nutrition in rat male pups was shown to affect dendritic branching in certain locations of rat brain, important in regulating attention status and the integration of motor and sensory activity, and this effect persisted in spite of later correction of nutritional deficits [13]. The potential vulnerability of the human brain to early suboptimal nutrition was reported by Lucas et al. The authors in their prospective randomised blinded trial observed that better nutrition of preterm newborn male infants was associated with a lower incidence of cerebral palsy and higher IQ scores at 7-8 years of age [14]. It is postulated that post-natal under-nutrition at a sensitive or critical period of brain growth or maturation influences the programming pathways in the brain permanently, influencing the cognitive performance later in the life $[15,16]$.

Post-natal growth retardation (PNGR) is common in the VLBW premature infants [17-19]. With increasing survival of premature infants, research is focused on decreasing the morbidities associated with premature birth. Provision of adequate nutrition soon after birth to match the fetal accretion rate, is important to reduce PNGR and associated impaired neuro-developmental, metabolic disorders and persistent short stature [20-25]. Thus evidence indicates that it may be critical to establish adequate nutrient supply soon after birth to prevent long term adverse effects of inadequate nutrition.

\section{SPN vs. IPN}

The studies comparing nutrient intakes during SPN and IPN are mostly non-randomised cohort studies, some favouring IPN while others SPN (Table 1) [26-31]. The only randomized controlled trial (RCT) comparing IPN with SPN enrolled only a small number of neonates [27]. The authors assigned 28 neonates requiring PN in either SPN or IPN group. They found that IPN led to better intake of calories, protein and lipids; and resulted in improved weight gain as compared with SPN. Glucose was the most common component of PN, which needed to be adjusted in SPN group. The adjustment was in the form of addition of dextrose to the SPN, which corrected the glucose homeostasis but diluted the amino acids resulting in decreased protein intake in SPN group [27]. Similarly, increased nutrient intakes with the use of IPN were also seen in a retrospective observational study by Mulchie et al. [26]. 
Table 1. Standardised $v s$. individualised PN—studies in neonates.

\begin{tabular}{|c|c|c|c|c|c|}
\hline $\begin{array}{c}\text { Author } \\
\text { [ref.] (Year) }\end{array}$ & Location & $\begin{array}{c}\text { Number of } \\
\text { study subjects }\end{array}$ & Age group & $\begin{array}{l}\text { Study } \\
\text { design }\end{array}$ & $\begin{array}{c}\text { Summary } \\
\text { of results }\end{array}$ \\
\hline $\begin{array}{c}\text { Mulchie } \\
\text { [26] (1979) }\end{array}$ & $\begin{array}{c}\text { Paediatric } \\
\text { Hospital }\end{array}$ & 12 & $\begin{array}{l}<36 \text { days, } \\
\text { mean GA } \\
35 \text { weeks }\end{array}$ & Cohort & $\begin{array}{l}\text { Mean weight gain in SPN } \\
\text { group was } 4 \mathrm{~g} / \text { day } v s . \\
17 \mathrm{~g} / \text { day in IPN group. }\end{array}$ \\
\hline $\begin{array}{l}\text { Dice [27] } \\
(1981)\end{array}$ & NICU & 28 & $\begin{array}{l}\text { Mean GA } \\
31 \text { weeks }\end{array}$ & $\mathrm{RCT}$ & $\begin{array}{l}\text { IPN group received } \\
\text { significantly higher energy } \\
\text { and protein intake and had } \\
\text { significantly higher weight } \\
\text { gain }(11.8 \text { vs. } 4.9 \mathrm{~g} / \text { day }) .\end{array}$ \\
\hline $\begin{array}{l}\text { Yeung [28] } \\
\quad(2003)\end{array}$ & NICU & $\begin{array}{c}31 \mathrm{in} \\
1999 / 2000 \\
(\mathrm{IPN}) v s .27 \mathrm{in} \\
2000 / 1(\mathrm{SPN})\end{array}$ & $\begin{array}{c}\mathrm{GA}<33 \\
\text { weeks }\end{array}$ & Cohort & $\begin{array}{l}\text { SPN group received } \\
\text { significantly more proteins } \\
\text { each day; and more calcium } \\
\text { and phosphate on day } 3 \text {. } \\
\text { SPN was associated with } \\
\text { significant cost reduction. }\end{array}$ \\
\hline $\begin{array}{c}\text { Lenclen [29] } \\
\quad(2006)\end{array}$ & NICU & $\begin{array}{l}20 \text { in } 2001 \\
(\mathrm{IPN}) v s .20 \text { in } \\
2003(\mathrm{SPN})\end{array}$ & $\begin{array}{c}\mathrm{GA}<32 \\
\text { weeks }\end{array}$ & Cohort & $\begin{array}{l}\text { On day } 3 \text {, intakes of } \\
\text { carbohydrates and } \\
\text { AA were higher; and } \\
\text { calcium phosphate } \\
\text { intakes were better } \\
\text { balanced in SPN group. }\end{array}$ \\
\hline $\begin{array}{c}\text { Smolkin } \\
{[30](2010)}\end{array}$ & NICU & $\begin{array}{c}70 \text { in } \\
2000-2001 \\
\text { (SPN) vs. } 70 \text { in } \\
2006-2007 \\
\text { (IPN) }\end{array}$ & $\begin{array}{l}\text { VLBW } \\
\text { newborn } \\
\text { infants }\end{array}$ & Cohort & $\begin{array}{l}\text { IPN group received } \\
\text { significantly higher daily } \\
\text { intake of glucose, protein } \\
\text { and fat; and achieved full } \\
\text { enteral feeds faster. }\end{array}$ \\
\hline $\begin{array}{c}\text { Iacobelli } \\
\text { [31] (2010) }\end{array}$ & NICU & $\begin{array}{c}40 \text { in } 2006 \\
(\mathrm{IPN}) v s .67 \text { in } \\
2006-2007 \\
(\mathrm{SPN})\end{array}$ & $\begin{array}{c}\mathrm{GA}<33 \\
\text { weeks }\end{array}$ & Cohort & $\begin{array}{l}\text { SPN group received } \\
\text { significantly more glucose, } \\
\text { AA, lipids, sodium and } \\
\text { magnesium. SPN was } \\
\text { associated with } \\
\text { significantly reduced } \\
\text { weight loss on day } 7 .\end{array}$ \\
\hline
\end{tabular}

GA: Gestational age at birth; SPN: Standardised parenteral nutrition; IPN: Individualised parenteral nutrition; NICU: Neonatal Intensive Care Unit; RCT: Randomised controlled trial; AA: Amino acids.

Smolkin et al. in a retrospective observational study involving 140 VLBW neonates reported that IPN was associated with significantly greater weight gain during the first month of life, greater discharge weight, shorter duration of PN requirement and more electrolyte stability [30]. The authors attributed the difference to the "richer" nutrition contents of IPN as compared with SPN. A weakness of the study was a long interval of six years between the two study periods, SPN cohort from year 2000 to 2001 and IPN cohort from year 2006 to 2007, with the possibility of change in the clinical care contributing to the outcome [30]. 
Other studies have reported favourable outcome with SPN when compared with IPN [28,29,31]. Lenclen et al. in their observational study reported that SPN provided higher early intakes of amino acids and glucose, and a better calcium phosphate ratio [29]. Improvement in nutrient intakes obtained by using SPN was because of less deviation from the protocol and earlier start of PN after birth [29]. Yeung et al. in their retrospective observational study in neonates $<33$ weeks gestational age found a similar benefit of improved nutrient intake with SPN [28]. The authors found that when compared with IPN, SPN was associated with 35\% less cumulative deficit in protein intake by the end of first week and, higher calcium and phosphate intakes. They did not find any clinical advantage of improved biochemical control with the IPN regimen [28]. Similar findings of higher protein and energy intakes without an increased risk of metabolic disturbances were also reported by Iacobelli et al. in their prospective observational study involving 107 neonates born at $<33$ weeks gestation [31].

\section{Early and Aggressive Nutrition}

It is a well-known fact that preterm neonates have limited energy reserves at birth and adequate provision of calories and protein to match intrauterine accretion rate soon after birth is required to prevent catabolic state [32]. The practice is often referred as "Aggressive" nutrition. One advantage of SPN is the ready availability in NICUs enabling initiation of the PN within a hour of birth [29,33]. IPN on the other hand is often not available especially afterhours. Starting PN within hours of birth has been found to be associated with positive nitrogen balance and calorie intake without increasing the risk of metabolic complications [34,35]. Aggressive intakes of amino acids in the range of $2.5-3 \mathrm{~g} / \mathrm{kg} /$ day starting on day one of life are well tolerated. [35,36]. The use of such aggressive nutrient intake is associated with increased protein accretion, decreased PNGR, better potassium homeostasis with decreased incidence of non-oliguric hyperkalemia, and decreased incidence of hyperglycemia by stimulation of endogenous insulin secretion. [31,37-40]. In a recent prospective observational study by Senterre and Rigo, ready-to-use SPN formulation was effective to limit the cumulative nutritional deficit and PNGR by providing early and aggressive nutrition to preterm neonates less than $1250 \mathrm{~g}[40,41]$.

\section{Electrolytes Homeostasis}

Renal and liver functions in the premature neonates continue to develop after birth. In addition, fluid and electrolyte balance is affected by extra-renal systems, illness, medications and interventions [42]. The fixed electrolyte contents of SPN may not be tolerated well by the sick premature neonates. However, Devlieger et al. proposed that the premature neonates are capable, within certain limits, of appropriate homeostasis as early as the first week of life and hence may be managed with few combinations of standard PN formulations [43]. The authors found that SPN formulations were sufficient to manage most of the VLBW neonates without significant electrolyte disturbances [43]. An advantage of IPN is the ability to make changes in the electrolyte composition of the PN to suit the neonates. However, there is often a delay (up to $24 \mathrm{~h}$ ) between the blood sampling and the administration of the TPN making changes in the PN based on these blood results far from ideal and possibly at times deleterious to biochemical homeostasis [43]. 


\section{Errors/Variations}

$\mathrm{PN}$ is one of the most complex medications with more than 50 constituents. There are multiple stages in the process of PN management where errors can occur: prescribing, transcription, preparation, and administration [44]. In an observational study in the adult patients receiving PN in an academic teaching general hospital, Sacks et al. found that out of 4730 PN prescriptions, $1.6 \%$ were associated with an error. Most of the errors occurred in transcription and administration process $[45,46]$. Studies have reported that IPN is associated with a high incidence of medical errors and protocol deviations [47] while SPN formulations have been associated with significantly less prescription errors in adult patients [48]. We did not find any study describing frequency of prescription errors while writing paediatric or neonatal PN prescriptions. It has been reported that individualized PN forms are oriented towards those who compound PN formulations and have been designed for ease of pharmacy usage; whereas, standardized PN forms are oriented toward ease of physician use. In a study by Mitchell et al. in adult patients, there was a substantial decrease in the prescription error and thus, a decrease in metabolic complications, with the use of standardized PN forms [49].

As use of PN has been increasing in the NICUs there is a need to establish prescription standards. Physicians, from attending staff to resident staff, differ greatly in their levels of nutrition education, especially in their familiarity with ordering the parenteral solutions. IPN puts more responsibility on the prescribing physicians to ensure adequate nutrient delivery [48]. The quality of IPN depends upon knowledge and attitude of the person ordering the PN. Optimal PN needs to be adequately prescribed and requires well trained physicians [2]. Studies have reported lack of education and knowledge regarding nutritional needs of neonates among doctors responsible for prescribing IPN [49]. SPN may provide the physician with a theoretically optimal starting point, and help standardise and optimise the PN prescription practices.

\section{Risk of Infection}

Administration of TPN, especially when prolonged, is associated with increased risk of late onset sepsis [50,51]. Most of the blood-stream infections (BSI) related to PN are caused by contamination of the device used for percutaneous vascular access; however, the fluid administered through the device also can become contaminated and cause BSI [52]. Various outbreaks of hospital-acquired infections have been reported through administration of contaminated PN because of lapses in sterility during compounding PN at hospital pharmacy [53]. SPN especially when commercially prepared may decrease chances of contamination of PN [54].

\section{Cost}

PN therapy is relatively expensive therapy, especially when personnel cost for patient monitoring, catheter care, and solution compounding are added to material cost. TPN compounding requires special, expensive equipment and infrastructure. Increasing use of TPN in relatively smaller units has created administrative and clinical challenges for hospital pharmacies. SPN may be the solution for such small hospitals if found to be well tolerated by neonates. SPN decreases processing and compounding time; and material cost for PN [48]. These resources can be utilized for other purposes in 
resource-restricted settings. SPN was associated with 30\% reduction in the cost of PN in a study by Yeung et al. [28]. SPN decreased solution wastage, labor and material costs, and inventory-holding costs, resulting in a 56\% decrease in annual TPN related expenditures [55]. Similar findings of reduced cost with SPN were also reported by Roberts et al. (1981), and Petros et al. (1986) [48,56].

\section{3-in-1 PN (Total Nutrient Admixtures)}

Total nutrient admixture (TNA), single mixture of all the components of PN, has been found to be safe and well tolerated in adults [48,57-60]. Perceived advantages of TNA system in adults include shorter time required for daily administration of PN resulting in decrease in nursing time and cost for patient care; and decrease in the risk of formula and vascular access contamination related to reduction of preparation steps, fewer solution containers, decreased violations of the central catheter, avoidance of piggybacking and the inadvertent dislodgement of the additional infusion tubing $[55,56,58,61]$. However, there is little data regarding its use in neonatal population.

Intravenous fat emulsions (IVFE) are found to be associated with increased risk for bacterial and fungal sepsis [61-63]. IVFE poses a major risk for sepsis in premature infants because of its favourable $\mathrm{pH}$ for growth of bacteria and fungi. In addition, lack of small volume containers, from manufacturers, appropriate for premature infants requires it to be repackaged in the pharmacy. Repackaging of intravenous fat emulsions even using aseptic technique under International Organisation for Standardization (ISO) class 5 conditions was associated with $1.7 \%$ rate of contamination $[64,65]$. 3-in-1 PN preparations may provide some protective effect for lipid emulsion associated BSI.

Recently, 3-in-1 PN has become available as a triple chamber system (Numeta ${ }^{\circledR}$, Baxter International Inc.); (Figure 1) for use in paediatric and neonatal population. The product has been licensed in 16 European countries; however, is not yet available in USA and Australia. The bag contains a glucose solution $(13 \%, 16 \%$ or $19 \%)$, a paediatric amino acid solution (Primene ${ }^{\circledR}$, Baxter $^{\circledR}$ ) with electrolytes and olive oil based lipid emulsion $\left(\right.$ ClinOleic $^{\circledR}$, Baxter $^{\circledR}$ ) in different compartments separated by seal, which can be broken to mix the components just before administration. Having the major components of PN separate prolongs its shelf life. Shelf life of Numeta ${ }^{\circledR}$ triple chamber PN bag is 18 months. It remains stable for $48 \mathrm{~h}$ at $30^{\circ} \mathrm{C}$ after mixing of the components [66]. The bag also gives a choice of withholding lipids, by keeping the seal unbroken between the lipid emulsion and the rest of the PN compartment. The preparation does not contain trace elements and vitamins, which are added into the final mixture separately as per clinical needs of the patients. The product has some unique components (ClinOleic, Primene and sodium glycerophosphate hydrated) which are not commercially available in USA.

A recent study by Rigo et al. evaluated safety and feasibility of the triple-chamber bag in 97 premature neonates [67]. The triple-chamber bag PN was administered for a minimum of 5 days and maximum of 10 days. The authors found that PN administration using commercially available triple chamber bag was safe and practical in premature neonates [67]. Additional supplementation, mainly of sodium, was needed to be performed in $45 \%$ infusion days, primarily using a Y-line; while additions directly to the triple chamber bag occurred on $21 \%$ infusion days in $37 \%$ infants. The authors found the nutritional intake in the range of "aggressive" nutrition recommendation and weight gain of $22 \mathrm{~g} / \mathrm{kg} /$ day after the first week of life in their infants suggesting use of triple-chamber bag may reduce 
post-natal growth deficit. Absence of a control group is an important limitation, as mentioned by authors, of this study [67,68].

\section{Conclusion}

Provision of adequate nutrition without causing biochemical derangement is an integral part of neonatal intensive care management. SPN may have advantages over IPN with respect to higher nutrient intake and weight gain; and less prescription errors and cost; without causing significant biochemical disturbance. Recently introduced ready-to-use all-in-one PN preparations for neonatal use may have additional advantages of ease of administration and decreased risk of infection.

Figure 1. Numeta ${ }^{\circledR}$ (Baxter ${ }^{\circledR}$ International Inc.) triple chamber bag for neonatal use.

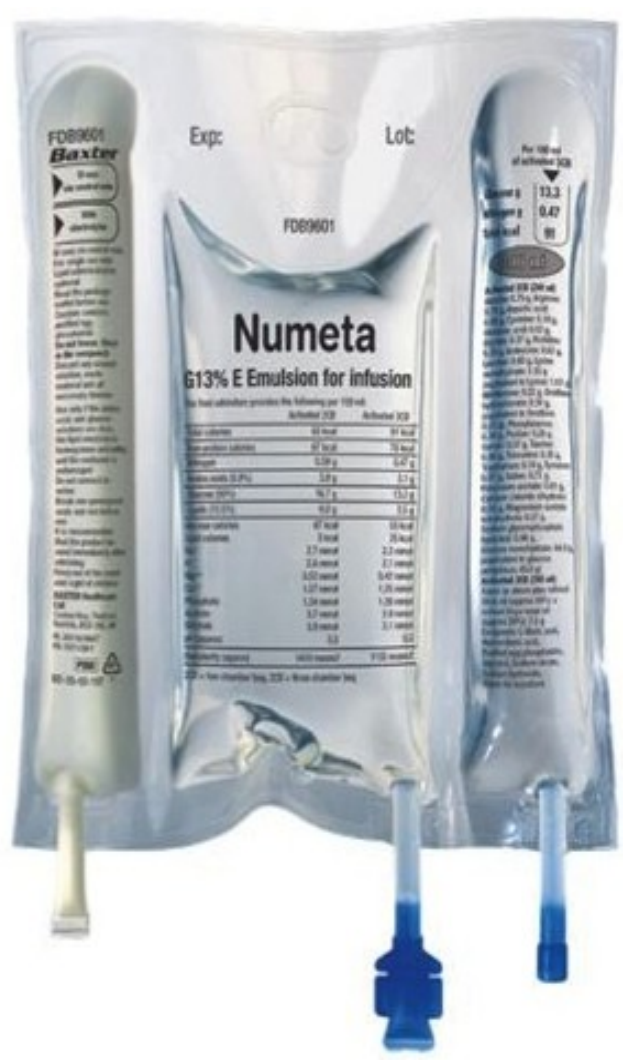

\section{Future Directions}

Well-controlled randomised controlled trials are needed to establish the role of SPN in the neonatal population including the safety, efficacy and feasibility of triple chamber bag TPN in preterm infants. The studies ideally need to evaluate not only the short term outcomes but also the long term outcomes - such as growth, neuro-developmental outcome and association with metabolic disorders - as rapid weight gain in neonatal period may be associated with increased risk of insulin resistance and obesity in adulthood [22].

\section{$\underline{\text { Key Points }}$}

- SPN may be well tolerated by very premature newborn infants without significant biochemical disturbances. 
- SPN may have advantages over the IPN in terms of less prescription and administration errors, decreased risk of infection, and cost savings.

- Triple chamber bag for TPN will provide an additional alternative for preterm neonates; however more well-controlled RCTs are needed measuring short term and long term outcomes.

\section{Conflict of Interest}

The authors declare no conflict of interest.

\section{References}

1. Beecroft, C.; Martin, H.; Puntis, J.W.L. How often do parenteral nutrition prescriptions for the newborn need to be individualied? Clin. Nutr. 1999, 18, 83-85.

2. Lapillonne, A.; Fellous, L.; Mokthari, M.; Kermorvant-Duchemin, E. Parenteral Nutrition Objectives for Very Low Birth Weight Infants: Results of a Natinal Survey. J. Pediatr. Gastroenterol. Nutr. 2009, 48, 618-626.

3. Gobel, Y.; Koletzko, B.; Bohles, H.J.; Engelsberger, I.; Forget, D.; Le Brun, A.; Peters, J.; Zimmermann, A. Parenteral fat emulsions based on olive and soybean oils: A randomized clinical trial in preterm infants. J. Pediatr. Gastroenterol. Nutr. 2003, 37, 161-167.

4. Webb, A.N.; Hardy, P.; Peterkin, M.; Lee, O.; Shalley, H.; Croft, K.D.; Mori, T.A.; Heine, R.G.; Bines, J.E. Tolerability and safety of oil-based emulsion in critically ill neonates: A blinded randomized trial. Nutrition 2008, 24, 1057-1064.

5. Deshpande, G.C.; Simmer, K.; Mori, T.; Croft, K. Parenteral lipid emulsions based on olive oil compared with soybean oil in preterm ( $<28$ weeks' gestation) neonates: A randomized controlled trial. J. Pediatr. Gastroenterol. Nutr. 2009, 49, 619-625.

6. Koksal, N.; Kavurt, A.V.; Cetinkaya, M.; Ozarda, Y.; Ozkan, H. Comparison of lipid emulsions on antioxidant capacity in preterm infants receiving parenteral nutrition. Pediatr. Int. 2011, 53, 562-566.

7. Sala-Vila, A.; Barbosa, V.M.; Calder, P.C. Olive oil in parenteral nutrition. Curr. Opin. Clin. Nutr. Metab. Care 2007, 10, 165-174.

8. Deckelbaum, R.J. Intravenous lipid emulsions in pediatrics: Time for a change? J. Pediatr. Gastroenterol. Nutr. 2003, 37, 112-114.

9. Koletzko, B.; Goulet, O.; Hunt, J.; Krohn, K.; Shamir, R.; Parenteral Nutrition Guidelines Working Group; European Society for Clinical Nutrition and Metabolism; European Society of Paediatric Gastroenterology, Hepatology and Nutrition (ESPGHAN); European Society of Paediatric Research (ESPR). Guidelines on paediatric parenteral nutrition of the European Society of Paediatric Gastroenterology, hepatology and Nutrition (ESPGHAN) and the European Society for Clinical Nutrition and Metabolism (ESPEN), supported by the European Society of Paediatric Research (ESPR). J. Pediatr. Gastroenterol. Nutr. 2005, 41, S1-S87.

10. Dudrick, S.J.; Wilmore, D.W.; Vars, H.M.; Rhoades, J.E. Long-term total parenteral nutrition with growth, development and positive nitrogen balance. Surgery 1968, 64, 134-142.

11. Smart, J.L.; Massey, R.F.; Nash, S.C.; Tonkiss, J. Effects of early-life undernutrition in artificially reared rats: Subsequent body and organ growth. Br. J. Nutr. 1987, 58, 245-255. 
12. Smart, J.L. Malnutrition, learning and behaviour: 25 years on from the MIT Symposium. Proc. Nutr. Soc. 1993, 52, 189-199.

13. Escobar, C.; Salas, M. Dendritic branching of claustral neurons in neonatally undernourished rats. Biol. Neonate 1995, 68, 47-54.

14. Lucas, A.; Morley, R.; Cole, T.J. Randomised trial of early diet in preterm babies and later intelligent quotient. BMJ 1998, 317, 1481-1487.

15. Lucas, A.; Morley, R.; Cole, T.J.; Gore, S.M.; Lucas, P.J.; Crowle, P.; Pearse, R.; Boon, A.J.; Powell, R. Early diet in preterm babies and developmental status at 18 months. Lancet 1990, 335, 1477-1481.

16. Lucas, A.; Morley, R.; Isaacs, E. Nutrition and mental development. Nutr. Rev. 2001, 59, S24-S33.

17. Ehrenkranz, R.A.; Younes, N.; Lemons, J.A.; Fanaroff, A.A.; Donovan, E.F.; Wright, L.L.; Katsikiotis, V.; Tyson, J.E.; Oh, W.; Shankaran, S.; et al. Longitudinal growth of hospitalized very low birth weight infants. Pediatrics 1999, 104, 280-289.

18. Embleton, N.E.; Pang, N.; Cooke, R.J. Postnatal malnutrition and growth retardation: An inevitable consequence of current recommendations in preterm infants? Pediatrics 2001, 107, 270-273.

19. Cooke, R.J.; Ainsworth, S.B.; Fenton, A.C. Postnatal growth retardation: A universal problem in preterm infants. Arch. Dis. Child. Fetal Neonatal Ed. 2004, 89, F428-F430.

20. Latal-Hajnal, B.; von Siebenthal, K.; Kovari, H.; Bucher, H.U.; Largo, R.H. Postnatal growth in VLBW infants: Significant association with neurodevelopmental outcome. J. Pediatr. 2003, 143, $163-170$.

21. Hack, M.; Schluchter, M.; Cartar, L.; Rahman, M.; Cuttler, L.; Borawski, E. Growth of Very low birth infants to age 20 years. Pediatrcs 2003, 112, e30-e38.

22. Singhal, A.; Fewtrell, M.; Cole, T.J.; Lucas, A. Low nutrient intake and early growth for later insulin resistance in adolescents born preterm. Lancet 2003, 361, 1089-1097.

23. Ehrenkranz, R.A.; Dusick, A.M.; Vohr, B.R.; Wright, L.L.; Wrage, L.A.; Poole, W.K. Growth in the neonatal intensive care unit influences neurodevelopmental and growth outcomes of extremely low birth weight infants. Pediatrics 2006, 117, 1253-1261.

24. Fran, A.R.; Pohlandt, F.; Bode, H.; Mihatsch, W.A.; Sander, S.; Kron, M.; Steinmacher, J. Intrauterine, early neonatal, and postdischarge growth and neurodevelopmental outcome at 5.4 years in extremely preterm infants after intensive neonatal nutrition support. Pediatrics 2009, 123, e101-e109.

25. Vohr, B.R.; Allan, W.; Katz, K.H.; Schneider, K.C.; Ment, L.R. Early predictors of hypertension in prematurely born adolescents. Acta Paediatr. 2010, 99, 1812-1818.

26. Mutchie, K.D.; Smith, K.A.; MacKay, M.W.; Marsh, C.; Juluson, D. Pharmacist monitoring of parenteral nutrition: Clinical and cost effectiveness. Am. J. Hosp. Pharm. 1979, 36, 785-787.

27. Dice, J.E.; Burckart, G.J.; Woo, J.T.; Helms, R.A. Standardized versus Pharmacist-Monitored Individualised Parental Nutrition in low-birth weight Infants. Am. J. Hosp. Pharm. 1981, 38, 1487-1489. 
28. Yeung, M.Y.; Smyth, J.P.; Maheshwari, R.; Shah, S. Evaluation of standardized versus individualized total parenteral nutrition regime for neonates less than 33 weeks gestation. J. Paediatr. Child Health 2003, 39, 613-617.

29. Lenclen, R.; Crauste-Manciet, S.; Narcy, P.; Boukhouna, S.; Geffray, A.; Guerrault, M.N.; Bordet, F.; Brossard, D. Assessment of implementation of a standardized paenteral formulaton for early nutritionl support of very preterm infants. Eur. J. Pediatr. 2006, 165, 512-518.

30. Smolkin, T.; Diab, G.; Shohat, I.; Jubran, H.; Blazer, S.; Rozen, G.S.; Makhoul, I.R. Standardized versus individualized parenteral nutrition in very low birth weight infants: A comparative study. Neonatology 2010, 98, 170-178.

31. Iacobelli, S.; Bonsante, F.; Vintejoux, A.; Gouyon, J.B. Standardized parenteral nutrition in preterm infants: Early impact on fluid and electrolyte balance. Neonatology 2010, 98, 84-90.

32. Heird, W.C.; Driscoll, J.M., Jr.; Schullinger, J.N.; Grebin, B.; Winters, R.W. Intravenous alimentation in pediatric patients. J. Pediatr. 1972, 80, 351-372.

33. Riskin, A.; Shiff, Y.; Shamir, R. Parenteral nutrition in neonatology-To standardize or individualize? Isr. Med. Assoc. J. 2006, 8, 641-645.

34. Ibrahim, H.M.; Jeroudi, M.A.; Baier, R.J.; Dhanireddy, R.; Krouskop, R.W. Aggressive early total parental nutrition in low-birth-weight infants. J. Perinatol. 2004, 24, 482-486.

35. Te Braake, F.W.J.; van den Akker, C.H.P.; Wattimena, D.J.L.; Huijmans, J.G.M.; van Goudoever, J.B. Amino acid administration to premature infants directly after birth. J. Pediatr. 2005, 147, 457-461.

36. Bulbul, A.; Okan, F.; Bulbul, L.; Nuhoglu, A. Effect of low versus high early parenteral nutrition on plasma amino acid profiles in very low birth-weight infants. J. Matern. Fetal Neonatal Med. 2012, 25, 770-776.

37. Thureen, P.J.; Hay, W.W., Jr. Early aggressive nutrition in preterm infants. Semin. Neonatol. 2001, 6, 403-415.

38. Whitfield, J.M.; Hendrikson, H. Prevention of protein deprivation in the extremely low birth weight infant: A nutritional emergency. Proc. Bayl. Univ. Med. Cent. 2006, 19, 229-231.

39. Bonsante, F.; Iacobelli, S.; Chantegret, C.; Martin, D.; Gouyon, J.-B. The effect of parenteral nitrogen and energy intake on the electrolyte balance in the preterm infant. Eur. J. Clin. Nutr. 2011, 65, 1088-1093.

40. Senterre, T.; Rigo, J. Optimizing early nutritional support based on recent recommendations in VLBW infants and postnatal growth restriction. J. Pediatr. Gastroenterol. Nutr. 2011, 53, 536-542.

41. Senterre, T.; Rigo, J. Reduction in postnatal cumulative nutritional deficit and improvement of growth in extremely preterm infants. Acta Paediatr. 2012, 101, e64-e70.

42. Modi, N. Fluid and Electrolyte Balance. In Robertson's Textbook of Neonatology, 4th ed.; Rennie, J.M., Ed.; Elsevier Limited: Philadelphia, PA, USA, 2005; pp. 334-354.

43. Devlieger, H.; de Pourco, L.; Casneuf, A.; Vanhole, C.; de Zegher, F.; Jaeken, J.; Eggermont, E. Standard two-compartment formulation for total parenteral nutrition in the neonatal intensive care unit: A fluid tolerance based system. Clin. Nutr. 1993, 12, 282-286.

44. Flynn, E.A.; Pearson, R.E.; Barker, K.N. Observational study of accuracy in compounding i.v. admixtures at five hospitals. Am. J. Health Syst. Pharm. 1997, 54, 904-912. 
45. Sacks, G.S.; Rough, S.; Kudsk, K.A. Frequency and severity of harm of medication errors related to the parenteral nutrition process in a large university teaching hospital. Pharmacotherapy 2009, 29, 966-974.

46. Sacks, G.S. Safety surrounding parenteral nutrition systems. JPEN J. Parenter. Enteral Nutr. 2012, 36, S20-S22.

47. Eleni-dit-Trolli, S.; Kermorvant-Duchemin, E.; Huon, C.; Mokthari, M.; Husseini, K.; Brunet, M.L.; Dupont, C.; Lapillonne, A. Early individualised parenteral nutrition for preterm infants. Arch. Dis. Child. Fetal Neonatal Ed. 2009, 94, F152-F153.

48. Petros, W.P.; Shnk, W.A. A standardised parenteral nutrition solution: Prescribing, use, processing, and material cost implications. Hosp. Pharm. 1986, 21, 648-656.

49. Mitchell, K.A.; Jones, E.A.; Meguid, M.M.; Curtas, S. Standardized TPN order forms reduces staff time and potential for error. Nutrition 1990, 6, 457-460.

50. Goldman, D.A.; Maki, D.G.; Rhame, F.S.; Kaiser, A.B.; Tenney, J.H.; Bennett, J.V. Guidelines for infection control in intravenous therapy. Ann. Intern. Med. 1973, 79, 848-850.

51. Williams, W.W. Infection control during parenteral nutrition therapy. JPEN J. Parenter. Enteral Nutr. 1985, 9, 735-746.

52. Maki, D.G. Infections Caused by Intravascular Devices for Infusion Therapy: Pathogenesis, Prevention and Management. In Infections Associated with Indwelling Medical Devices, 2nd ed.; Bisno, A.L., Waldvogel, F.A., Eds.; American Society of Microbiology: Washington, DC, USA, 1994; pp. 155-211.

53. Sacks, G.S. Microbial contamination of parenteral nutrition-How could it happen? JPEN J. Parenter. Enteral Nutr. 2011, 35, 432.

54. Zingg, W.; Tomaske, M.; Martin, M. Risk of parenteral nutrition in neonates-An overview. Nutrients 2012, 4, 1490-1503.

55. Maswoswe, J.J.; Newcomer, D.R.; Quandt, C.M. Achieving parenteral nutrition cost savings through prescribing guidelines and formulary restrictions. Am. J. Hosp. Pharm. 1987, 44, 1376-1381.

56. Roberts, M.J.; Teasley, K.M.; Roberts, A.W. Pharmacy program to reduce parenteral nutrition costs. Am. J. Hosp. Pharm. 1981, 38, 1519-1520.

57. Ahemed, M.; Irwin, S.; Tuthill, D.P. Education and Evidence are needed to improve neonatal parenteral nutrition practice. JPEN J. Parenter. Enteral Nutr. 2004, 28, 176-179.

58. Rowe, C.E.; Fukuyama, T.T.; Martinoff, J.T. Growth of microorganisms in total nutrient admixtures. Drug Intell. Clin. Pharm. 1987, 21, 633-638.

59. Campos, A.C.; Paluzzi, M.; Meguid, M.M. Clinical use of total nutritional admixtures. Nutrition 1990, 6, 347-356.

60. Driscoll, D.F. Clinical issues regarding the use of total nutrient admixtures. DICP Ann. Pharmacother. 1990, 24, 296-303.

61. Didier, M.E.; Fischer, S.; Maki, D.G. Total nutrient admixtures appear safer than lipid emulsion alone as regards microbial contamination: Growth properties of microbial pathogens at room temperature. JPEN J. Parenter. Enteral Nutr. 1998, 22, 291-296. 
62. Pichard, C.; Schwarz, G.; Frei, A.; Kyle, U.; Jolliet, P.; Morel, P.; Romand, J.A.; Sierro, C. Economic investigation of the use of three-compartment total parenteral nutrition bag: Prospective randomized unblended controlled study. Clin. Nutr. 2000, 19, 245-251.

63. Ashcraft, K.W.; Leape, L.L. Candida sepsis complicating parenteral feeding. JAMA 1970, 212, 454-456.

64. Kuwahara, T.; Shimono, K.; Kaneda, S.; Tamura, T.; Ichihara, M.; Nakashima, Y. Growth of microorganisms in total parenteral nutrition solutions containing lipid. Int. J. Med. Sci. 2010, 7 , 101-109.

65. Reiter, P.D. Sterility of intravenous fat emulsion in plastic syringes. Am. J. Health Syst. Pharm. 2002, 59, 1857-1859.

66. Summary of Product Characteristics. Available online: http://www.ecomm.baxter.com/ecatalog/ loadResource.do?bid=52811 (access on 21 March 2013).

67. Rigo, J.; Marlowe, M.L.; Bonnot, D.; Senterre, T.; Lapillonne, A.; Kermorvant-Duchemin, E.; Hascoet, J.M.; Desandes, R.; Malfilatre, G.; Pladys, P.; et al. Benefits of new pediatric triple-chamber bag for parenteral nutrition in preterm infants. JPEN J. Parenter. Enteral Nutr. 2012, 54, 210-217.

68. Ziegler, E.E.; Thureen, P.J.; Carlson, S.J. Aggressive nutrition of the very low birth-weight infant. Clin. Perinatol. 2002, 29, 225-244.

(C) 2013 by the authors; licensee MDPI, Basel, Switzerland. This article is an open access article distributed under the terms and conditions of the Creative Commons Attribution license (http://creativecommons.org/licenses/by/3.0/). 